University of Nebraska - Lincoln

DigitalCommons@University of Nebraska - Lincoln

Nebraska Game and Parks Commission -- Staff

Research Publications

Nebraska Game and Parks Commission

9-6-2019

\title{
Condition Bias of Decoy-Harvested Light Geese During the Conservation Order
}

Drew N. Fowler

University of Missouri, drew.fowler@wisconsin.gov

Elisabeth B. Webb

University of Missouri

Mark P. Vrtiska

Nebraska Game and Parks Commission, Lincoln, mark.vrtiska@nebraska.gov

Follow this and additional works at: https://digitalcommons.unl.edu/nebgamestaff

Fowler, Drew N.; Webb, Elisabeth B.; and Vrtiska, Mark P., "Condition Bias of Decoy-Harvested Light Geese During the Conservation Order" (2019). Nebraska Game and Parks Commission -- Staff Research Publications. 97.

https://digitalcommons.unl.edu/nebgamestaff/97

This Article is brought to you for free and open access by the Nebraska Game and Parks Commission at DigitalCommons@University of Nebraska - Lincoln. It has been accepted for inclusion in Nebraska Game and Parks Commission -- Staff Research Publications by an authorized administrator of DigitalCommons@University of Nebraska - Lincoln. 


\title{
Condition Bias of Decoy-Harvested Light Geese During the Conservation Order
}

\author{
DREW N. FOWLER, ${ }^{1}$ Missouri Cooperative Fish and Wildlife Research Unit, University of Missouri, Columbia, MO 65211, USA \\ ELISABETH B. WEBB, U.S. Geological Survey, Missouri Cooperative Fish and Wildife Research Unit, University of Missouri, Columbia, \\ MO 65211, USA
}

MARK P. VRTISKA, Nebraska Game and Parks Commission, Lincoln, NE 68503, USA

\begin{abstract}
Evidence that decoy harvest techniques primarily remove individuals of poorer body condition is well established in short-lived duck species; however, there is limited support for condition bias in longer-lived waterfowl species, such as geese, where decoy harvest is considered primarily additive because of their high natural survival rates. We evaluated support for the harvest condition bias hypothesis of 2 long-lived waterfowl species, the lesser snow goose (Anser caerulescens caerulescens) and Ross's goose (Anser rossii). We used proximate analysis to quantify lipid and protein content of lesser snow and Ross's geese collected during the Light Goose Conservation Order (LGCO) in 2015 and 2016 during spring migration in Arkansas, Missouri, Nebraska, and South Dakota, USA. In each state, LGCO participants collected birds using traditional decoy techniques and we collected birds from the general population using jumpshooting tactics. Total body lipid content in both lesser snow and Ross's geese varied with age, region of harvest, and harvest type (decoy or jump-shooting). On average, adult lesser snow and Ross's geese harvested over decoys had $60 \mathrm{~g}$ and $41 \mathrm{~g}$, respectively, fewer lipids than conspecifics collected using jumpshooting. We observed lower lipid reserves in decoy-shot geese in all 4 states sampled despite general gains in lipid reserves as migration chronology progressed. Our data support that the harvest condition bias extends to longer-lived waterfowl species and during a life-history event (spring migration) in which harvest is not normally observed. In the case of overabundant light geese, the disproportionate harvest of poorerconditioned lesser snow and Ross's geese may serve as an additional challenge against any realized effects of harvest to reduce the population, in addition to extremely low harvest rates. (C) 2019 The Wildlife Society.
\end{abstract}

KEY WORDS Anser, body condition, lesser snow geese, proximate analysis, Ross's geese.

Effects of harvest mortality on waterfowl populations can be additive to sources of natural mortality or compensatory, such that for a range of harvest rates up until a threshold, harvest has no change in overall survival (or total mortality; Anderson and Burnham 1976, Sedinger and Herzog 2012). Additive and compensatory mortality are likely best conceptualized as opposite endpoints on a continuum, along which variations in life history among species, harvest and environmental pressures, and population heterogeneity can result in a partial compensatory harvest effect (Conroy and Krementz 1990, Lebreton 2005, Lindberg et al. 2013). Therefore, harvest mortality on this continuum can greatly affect the potential for harvest to influence waterfowl populations (Cooch et al. 2014).

Density dependence and individual heterogeneity (or some combination) are 2 often-identified underlying mechanisms for wildlife populations experiencing some degree of compensatory harvest effects. Compensatory harvest mortality can offset

Received: 7 February 2019; Accepted: 6 September 2019

\footnotetext{
${ }^{1}$ E-mail: drew.fowler@wisconsin.gov; dnftgb@mail.missouri.edu
}

natural mortality by alleviating a density-dependent pressure, such as limited habitat availability, so that if harvest mortality is high, natural mortality will decline (Nichols 1991, Johnson et al. 1993). In contrast, when harvest mortality is low in populations experiencing density dependence, natural mortality will be greater (Lebreton 2005, Cooch et al. 2014). Support for density dependence as a mechanism for compensatory harvest, particularly in ducks, has been equivocal (Pöysä et al. 2004, Viljugrein et al. 2005, Murray et al. 2010, Sedinger and Herzog 2012), but it is evident that densitydependent pressures must be substantial to affect adult survival rates (Bonenfant et al. 2009). Nonetheless, individual variation in survival can serve as a mechanism for compensation and can have implications for effects of harvest on population change (Lebreton 2005, Caudill et al. 2017). Caudill et al. (2017) demonstrated that given some degree of additive harvest in a population comprised of groups with heterogeneous survival rates, disproportionate harvest of low-quality individuals (i.e., those with lower survival and reproductive rates) will induce partial compensation. Therefore, even in the absence of density dependence and with substantial harvest rates, bias towards harvest of low-quality individuals can reduce harvest effects on population reduction (Lebreton 2005, Cooch et al. 2014). 
Individual heterogeneity in survival can result from a variety of factors including phenotype or genotype (Gimenez et al. 2018) and reproductive success (Iverson et al. 2014, Calvert et al. 2019); however, these factors are often mediated through a proximate mechanism, body condition (Owen and Black 1989, Hill et al. 2003, Blums et al. 2005). Regarding harvest mortality in duck species, individuals in poorer body condition are generally more vulnerable to harvest (Greenwood et al. 1986, Sheeley and Smith 1989, Dufour et al. 1993, Pace and Afton 1999). Inherent to the harvest condition bias hypothesis is that nutrient reserve levels influence harvest vulnerability and receptiveness to decoys, where nutrient-deficient individuals are more risk prone and experience greater harvest (Greenwood et al. 1986, Reinecke and Shaiffer 1988). Accordingly, hunter-harvested ducks are hypothesized to have lower natural survival probabilities than those not harvested (Sedinger and Herzog 2012, Péron 2013). Compared to other waterfowl, ducks are short-lived species and are therefore expected to display greater levels of heterogeneity in survival probabilities relative to longer-lived species that implement bet-hedging strategies to minimize annual mortality risks and buffer against genetic and environmental perturbations through a process known as canalization (Waddington 1953, Nevoux et al. 2010, Péron et al. 2016).

Tests of the condition bias hypothesis have been limited among longer-lived waterfowl, such as geese. Inferences from the canalization hypothesis predict reduced individual heterogeneity in annual survival and body condition because of their longer life spans (Péron et al. 2016). Morez et al. (2000) did not find support for a harvest condition bias in either juvenile or adult decoy-harvested greater snow geese (Anser caerulescens atlanticus) relative to individuals captured in baited or un-baited rocket nets. Decoy-harvested individuals, however, did exhibit smaller structural size, suggesting that harvest may be phenotypically biased (Morez et al. 2000). This study occurred during fall migration and the authors stressed the importance for continued investigation of condition biases among waterfowl under a range of hunting conditions (Morez et al. 2000). Indeed, heterogeneous harvest vulnerability is likely to vary temporally and spatially given the extent of existing harvest pressures and spatial segregation of high- and low-quality individuals during migration (Lindberg et al. 2013). During spring migration, geese compete for food energy sources, largely in the form of lipids, to meet the energetic costs of migration, while also acquiring sufficient proteins and additional lipids for eventual clutch formation (Ankney and MacInnes 1978, Alisauskas 2002). Consequently, harvest pressure of greater snow geese in spring may induce non-lethal energetic costs that further facilitate condition biases of individuals subject to hunter mortality (Béchet et al. 2004).

Understanding the role of harvest when condition biases are present is particularly relevant in many worldwide goose populations given their overall increase and associated management decisions to control populations through harvest strategies (Alisauskas et al. 2011, Fox and Madsen 2017). If condition biases exist in geese, and across seasons (spring migration), then individual heterogeneity in harvest vulnerability resulting from differential body condition likely has additional implications for the effect of harvest on population change via compensatory mortality, beyond low rates of current take (Calvert et al. 2017). The lesser snow goose (A. caerulescens caerulescens) and the Ross's goose ( $A$. rossii; i.e., light geese) are species of arctic-nesting geese that experienced rapid population growth in the last half century (Batt 1997, Alisauskas et al. 2011). These 2 species and the greater snow goose, are currently the only species subject to legal harvest beyond the dates established by the Migratory Bird Treaty Act, commonly known as the Light Goose Conservation Order (LGCO; Batt 1997). Therefore, current harvest of light geese occurs throughout 3 major phases of the annual life-cycle: autumn migration, overwintering, and spring migration, each of which occurs in different geographic regions and exerts unique nutritional requirements (Alisauskas 2002, Hénaux et al. 2012).

Our objective was to evaluate variation in body size, body mass, and lipid and protein reserves between light geese harvested over decoys, the predominant method used by LGCO participants to harvest light geese in mid-latitude states, and light geese sampled by jump-shooting during spring migration. We predicted that individuals collected over decoys would have reduced lipid and protein levels and reduced overall body size relative to those collected by jumpshooting tactics owing to more risk-prone behavior resulting from nutrient deficiencies.

\section{STUDY AREA}

We collected light geese across east-central Arkansas and southeast Missouri (region 1), northwest Missouri (region 2), southeastern Nebraska (region 3), and eastcentral South Dakota (region 4), USA, during spring migration 2015 and 2016 (Fig. 1). These regions were characterized by intensive agricultural production of rice, corn, and winter wheat and typified landscape characteristics that light geese use during spring migration (Reinecke et al. 1989, Higgins et al. 2002, Abraham et al. 2005, U.S. Fish and Wildlife Service 2005, Webb et al. 2010). Furthermore, band recovery and harvest estimates indicated a greater proportion of light geese were harvested in these states compared to other states in the Mississippi and Central flyways and these states were considered key light goose staging areas during spring migration (Webb et al. 2010, Alisauskas et al. 2011, Kruse and Fronczack 2013).

\section{METHODS}

We obtained light geese from participants in the LGCO who harvested birds over decoys. In mid-latitude states, decoy hunting represents the dominate form of light goose harvest during the spring. From 2015 to 2018, median estimates of decoy harvest accounted for 70\%, 86\%, 68\%, and $75 \%$ of total goose harvest in Arkansas, Missouri, Nebraska, and South Dakota, respectively (L. W. Naylor, Arkansas Game and Fish Commission; A. H. Raedeke, Missouri Department of Conservation; M. P. Vrtiska, Nebraska Game and Parks Commission; and R. J. Murano, 


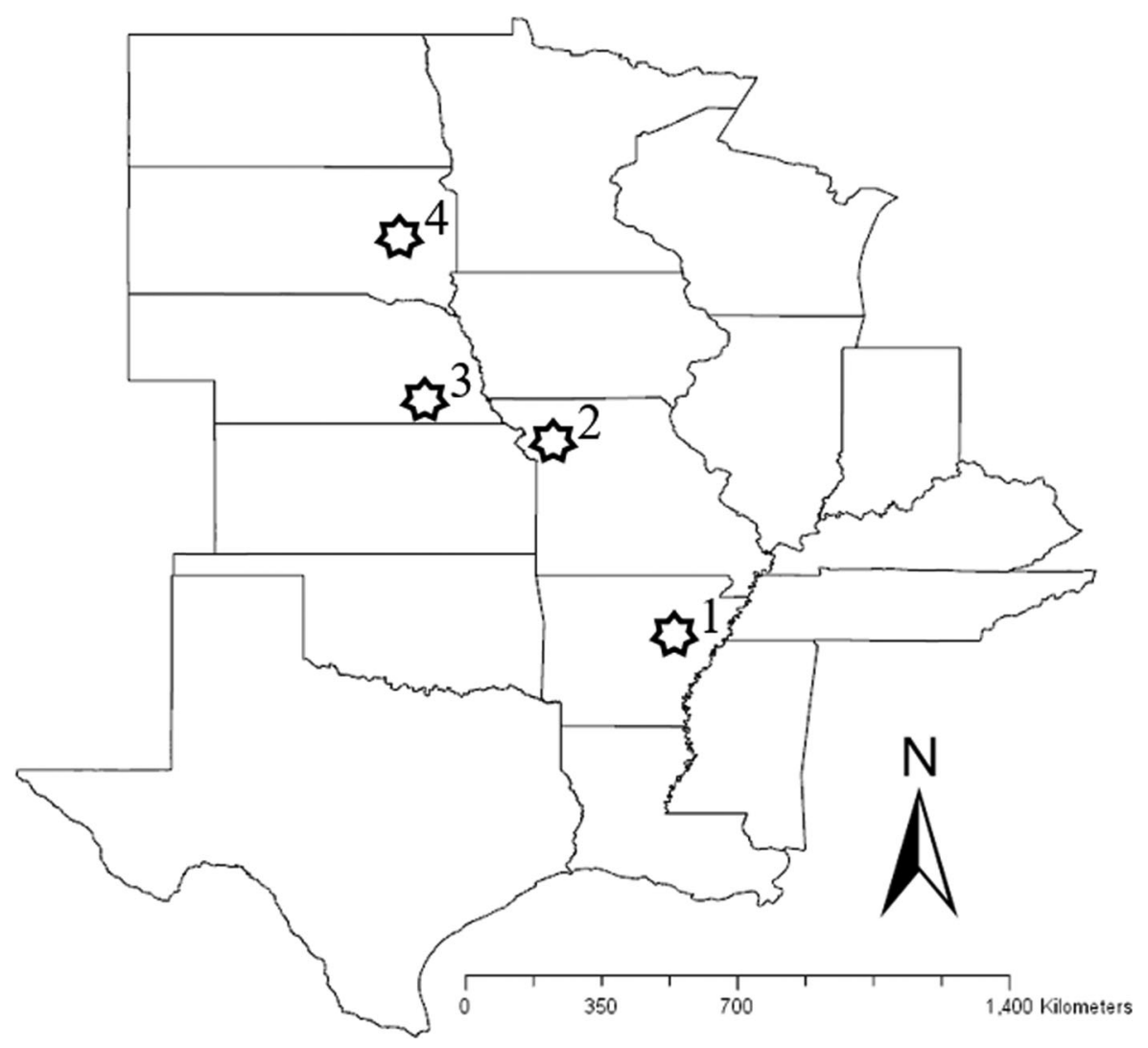

Figure 1. Sampling regions of lesser snow $(n=759)$ and Ross's geese $(n=154)$ collected during spring migration 2015 and 2016, in Arkansas, Missouri, Nebraska, and South Dakota, USA.

South Dakota Game, Fish, and Parks, unpublished data). Concurrently, we collected light geese by jump-shooting flocks feeding on land or loafing on water within $25 \mathrm{~km}$ of collection locations for decoy-harvested birds. For geese collected with jump-shooting techniques, we crept within shooting distance of a flock, stood to flush geese into the air and then collected 1-15 individuals from the mixed flock. The decision of when to collect geese for this study was mediated by both determination of peak migration in each region and the presence of LGCO participants. Often, the presence of LGCO participants in a region coincided with peak numbers of light geese in the area, but on occasion, we observed large numbers of light geese using a region as a stopover site where LGCO participants were not present. We therefore spatially and temporally limited our collections of jump-shot individuals to when LGCO participants were present. Avian body condition can fluctuate rapidly during migration because of substantial energetic expenditures related to flight movements or sudden changes in weather events (Jenni and Jenni-Eiermann 1998). Therefore, to make comparisons of body condition between decoy-harvested birds and those from the general population of geese, we attempted to collect both decoy and jumpshot birds within a 3-7-day time period in each region when weather conditions were generally consistent. When logistically possible, we collected decoy and jump-shot birds on the same day. To avoid potential sampling biases related to particular decoy hunting groups, we obtained samples from individual hunting parties only once. When logistically possible, we collected $\leq 15$ individuals per collection method each day, per region.

All light goose collections were conducted in accordance with a United States Fish and Wildlife Service scientific collection permit (MB47969B-1), Arkansas state permit (102320141), Missouri state permit (16217), Nebraska state permit (535), South Dakota state permit (1 and 5), and University of Missouri Animal Care and Use Committee permit (8191). Within 8 hours of collection, we assigned each bird a unique identification number and recorded the time and location of collection. Afterwards, we tagged and froze collected geese until dissection and analysis at the University of Missouri.

\section{Dissection and Chemical Analyses of Geese}

We aged light geese as hatch year (HY) or after hatch year (AHY) by plumage characteristics, foot color, and the absence of caruncles in Ross's geese and determined sex based on reproductive organs during dissections (Baldassarre 2014). We weighed thawed individuals to the nearest $0.5 \mathrm{~g}$. We measured head length, culmen length, and total tarsus length to the nearest $0.1 \mathrm{~mm}$, and measured body length and un-flattened wing chord to the nearest $\mathrm{mm}$ using a measuring board (Dzubin and Cooch 1992). A complete description of dissection methods and chemical analyses for collected geese is detailed in Fowler et al. (2018), but in brief, we shaved individuals of feathers to 
estimate muscular and cardiac protein and weighed and removed ingesta-contents to obtain ingesta-free body mass $(\mathrm{g})$. We ground individual carcasses (whole bird minus feather and ingesta contents) through an industrial meat grinder (Hobart 4146, Toledo, OH, USA) and then dried a subsample $(50.0 \mathrm{~g})$ to a constant mass. We submitted pulverized homogenates samples to the University of Missouri Agricultural Experiment Station Chemical Laboratory for proximate analysis of crude lipid and protein following standardized procedures (Alisauskas 2002, Horwitz 2006).

To account for potential correlation between nutrient levels and body size (Ankney and MacInnes 1978, Alisauskas 2002), we used a principal components analysis from the correlation matrix of body length, wing chord, head length, tarsus length, and culmen to derive the first principal component (PC1), which provided a univariate index of body size. Loadings of original variables on $\mathrm{PC} 1$ for lesser snow geese were 0.49 for head length, 0.47 for body length, 0.45 for culmen length, 0.41 for tarsus length, and 0.40 for wing chord. The first principal component accounted for $64 \%$ of variation in all variables. The first principal component for Ross's geese explained $62 \%$ of the variation in the same 5 variables and loadings included 0.47 for body length, 0.46 for culmen length, 0.46 for head length, 0.42 for tarsus length, and 0.42 for wing chord. Following Alisauskas (2002), we scaled ingesta-free body mass, lipid, and protein reserves to body size, using PC1 as an index, thus allowing for differences in sex, age, and harvest type to be evaluated while accounting for variation in body size.

\section{Model Fitting}

We developed models for 4 response variables for snow and Ross's geese: size-adjusted lipid reserves, size-adjusted protein reserves, size-adjusted ingesta-free body mass, and body size (represented by the univariate PC1). For models explaining variation in body condition, we formulated a single general linear mixed model using sex, age, harvest type, region of harvest, and year (random effect) as explanatory variables. To explain variation in body size, we built a single general linear model for each species using sex, age, and harvest type as explanatory variables. We avoided multiple model selection methods for philosophical and operational reasons (Clark 2007, Hobbs et al. 2012), primarily because of potential ambiguity and subjectivity of selecting a top model from a set of candidates (Kadane and Lazat 2004, Harrison et al. 2018). Instead, we developed models based on well-established, biological foundations that would address our specific research objective to evaluate the importance of harvest type in influencing body condition relative to other mechanistic parameters.

We analyzed general linear models using the base package of Program R (version, 3.3.3, R Development Core Team 2018) and used the lme 4 package for Program R (Bates et al. 2015) to formulate mixed-effects models. We assessed goodness of fit by calculating conditional and marginal $R^{2}$ values (Nakagawa and Schielzeth 2013) with the r.squaredGLMM function in the MuMIn package for
Program R (Barton 2017). We considered covariates significant when $95 \%$ confidence intervals did not overlap with zero. To estimate least square means (Harvey 1960) for factor combinations of interest and visualize model estimates and their effect size, we used the lmerTest package for Program R (Kuznetsova et al. 2017).

\section{RESULTS}

\section{Lesser Snow Geese}

We collected 354 lesser snow geese between 2 February and 31 March 2015 and 405 between 11 February and 7 March 2016. Among individuals collected in 2015, 185 (52\%) were harvested over decoys and 169 (48\%) were collected via jump-shooting. Females represented $43 \%$ of individuals harvested over decoys and $53 \%$ of the jump-shot sample. Adults represented $47 \%$ of lesser snow geese harvested over decoys and $84 \%$ of the jump-shot sample. In 2016, we collected 201 snow geese harvested over decoys (49\%) and 205 via jump-shooting (51\%). Similar trends in proportion of individuals collected between the 2 collection treatments in 2015 were also evident in 2016. Females comprised 42\% of the decoy sample and $52 \%$ of decoy-harvested individuals were adults. Jump-shooting samples consisted of $52 \%$ females and were heavily skewed to adults (94\%).

Lipid content in lesser snow geese varied based on interactions between harvest type and age, and harvest type and collection region. Our model explained approximately $28 \%$ of the overall variation in the lipid content, and the random effect of year accounted for $2 \%$ of the explained variation (Table 1). The least square mean estimate of lipids in decoy-harvested adult geese was $59.9 \mathrm{~g}$ (95\% $\mathrm{CI}=49.7-70.2 ; 38.7 \%$ decrease) lower than individuals collected by jump-shooting, and lipid content in HY decoyharvested geese was $29.7 \mathrm{~g}$ (95\% CI $=11.4-47.9 ; 16.5 \%$ decrease) lower than jump-shot individuals of the same age (Fig. 2A). Averaging across sex and age, least square mean estimate of lipid content in decoy-harvested individuals from Arkansas was $30.6 \mathrm{~g}$ (95\% CI $=14.1-46.9 ; 21.0 \%$ decrease) lower than jump-shot individuals (Fig. 3). Similarly, mean lipid content in decoy-harvested individuals from Missouri was $43.7 \mathrm{~g}$ (95\% CI $=26.3-61.2 ; 30.8 \%$ decrease) lower, and lipids in birds collected in Nebraska and South Dakota were $39.6 \mathrm{~g}$ (95\% CI $=22.7-56.4 ; 23.9 \%$ decrease) and $65.4 \mathrm{~g}$ (95\% CI $=46.9-83.9 ; 30.9 \%$ decrease), respectively, lower than lipids in individuals collected by jump-shooting (Fig. 3).

Protein content in lesser snow geese varied by the main effects of age and harvest region, but not by harvest type (Table 1; Fig. 2B). Our model explained approximately 17\% of overall variation in the data, and the random effect of year accounted for $3 \%$ of the explained variation (Table 1). Protein declined for all individuals with increasing latitude across the collection area such that protein content was $15.4 \mathrm{~g}$ (95\% CI $=9.8-24.1$; $4.0 \%$ decrease) lower in South Dakota relative to individuals collected in Arkansas. Averaging across sex, region, and harvest type, protein content was $17.5 \mathrm{~g}$ (95\% CI $=12.4-22.54 .6 \%$ decrease) lower in $\mathrm{HY}$ than AHY individuals. 
Table 1. Results of general linear mixed models explaining variation in lipid content (g), protein content (g), and ingesta-free body mass ( $\mathrm{g}$ ) of lesser snow geese ( $n=759)$ collected during the spring Light Goose Conservation Order in 2015 and 2016. Predictor variables included sex (male or female), age (after hatch year $[\mathrm{AHY}]$ or hatch year $[\mathrm{HY}])$, harvest region (AR, MO, NE, SD), and harvest type (decoy or jump-shot).

\begin{tabular}{|c|c|c|c|c|c|c|c|c|c|}
\hline \multirow[b]{2}{*}{ Variables } & \multicolumn{3}{|c|}{ Lipid model } & \multicolumn{3}{|c|}{ Protein model } & \multicolumn{3}{|c|}{ Body mass model } \\
\hline & Estimate & & $95 \% \mathrm{CI}$ & Estimate & & $95 \% \mathrm{CI}$ & Estimate & & 95\% CI \\
\hline Intercept $\mathrm{t}^{\mathrm{a}}$ & $89.66^{* * *}$ & \pm & 20.42 & $378.24^{\text {**** }}$ & \pm & 8.80 & $1865.55^{* * *}$ & \pm & 40.19 \\
\hline Age (HY) & $54.50^{* * *}$ & \pm & 11.75 & $-15.39^{* * * *}$ & \pm & 5.61 & -7.05 & \pm & 26.02 \\
\hline Region (MO) & -13.11 & \pm & 15.18 & $-8.40^{*}$ & \pm & 7.25 & $-82.98^{* * *}$ & \pm & 33.63 \\
\hline Region (NE) & 10.30 & \pm & 15.91 & $-12.85^{* * * *}$ & \pm & 7.59 & $-40.60^{*}$ & \pm & 35.24 \\
\hline Region (SD) & $30.53^{* * *}$ & \pm & 16.31 & $-18.43^{* * * *}$ & \pm & 7.78 & -6.68 & \pm & 36.12 \\
\hline Harvest type $\times$ region (jump, MO) & 13.17 & \pm & 22.13 & 1.50 & \pm & 10.56 & 48.90 & \pm & 49.02 \\
\hline Harvest type $\times$ region (jump, NE) & 9.05 & \pm & 22.31 & 1.24 & \pm & 10.65 & 20.64 & \pm & 49.42 \\
\hline Harvest type $\times$ region $($ jump, SD) & $34.88^{* *}$ & \pm & 23.14 & 6.05 & \pm & 11.05 & $123.32^{* * *}$ & \pm & 51.26 \\
\hline Marginal $R^{2}$ & & $0 . \overline{2} 6$ & & & $0 . \overline{14}$ & & & $0 . \overline{2} 8$ & \\
\hline Conditional $R^{2}$ & & 0.28 & & & 0.17 & & & 0.30 & \\
\hline Variance: year (intercept) & & 106.39 & & & 17.92 & & & 366.51 & \\
\hline
\end{tabular}

${ }^{*} P<0.05$.

** $P<0.01$.

*** $P<0.001$.

${ }^{a}$ Intercept referenced on adult female geese collected in Arkansas over decoys.

Ingesta-free body mass in lesser snow geese varied based on interactions between harvest type and age, and harvest type and collection region. Our model explained approximately $30 \%$ of the overall variation in the data, and the random effect of year accounted for $2 \%$ of the explained variation (Table 1). The least square mean estimate of ingesta-free body mass in decoy-harvested adult geese was $129.3 \mathrm{~g}(95 \% \mathrm{CI}=106.6-151.9 ; 6.6 \%$ decrease) lower than individuals collected by jump-shooting, and ingesta-free body mass in HY decoy-harvested geese was $77.6 \mathrm{~g}$ (95\% CI $=37.2-117.9 ; 4.1 \%$ decrease) lower than individuals collected by jump-shooting (Fig. 2C). Averaging across sex and age, the least square mean estimate of ingesta-free body mass in decoy-harvested individuals from Arkansas was $55.2 \mathrm{~g}$ (95\% CI $=17.6-92.8 ; 2.9 \%$ decrease) lower than jump-shot individuals. Similarly, ingesta-free body mass in decoy-harvested individuals from Missouri was $104.1 \mathrm{~g}$ (95\% CI $=65.4-142.8 ; 5.5 \%$ decrease) lower than individuals collected by jump-shooting. Ingesta-free body mass in decoy-collected birds in Nebraska and South Dakota was $75.8 \mathrm{~g}(95 \% \mathrm{CI}=38.4-113.2 ; 3.9 \%$ decrease $)$ and $178.5 \mathrm{~g}$ (95\% CI $=137.6-219.5 ; 8.8 \%$ decrease), respectively, lower than ingesta-free body mass in individuals collected by jump-shooting. Body size in lesser snow geese was not different between decoy-harvested and jump shot individuals (Fig. 2D) but varied with sex, age, and their interaction (Table 2).

\section{Ross' Geese}

We collected 87 Ross' geese between 2 February and 31 March in 2015, and 67 geese between 11 February and 7 March in 2016. Among individuals collected in 2015, 36 (41\%) were harvested over decoys and 51 (59\%) were collected via jump-shooting. Females represented 53\% of individuals harvested over decoys and $39 \%$ of the jump-shot sample. Adults represented $47 \%$ of Ross' geese harvested over decoys and $84 \%$ of individuals collected via jump-shooting. In 2016, 32 Ross' geese were harvested over decoys (48\%) and 35 were collected via jump-shooting (52\%). Adults comprised $72 \%$ of the decoy sample and only $32 \%$ of the decoy sample were females. Jump-shooting resulted in $49 \%$ females and was heavily skewed to adults (94\%).

Lipid content in Ross's geese varied with sex, region of harvest, and harvest type; however, interactions between harvest type and age, and harvest type and harvest region were not important (Table 3). Our model explained approximately $37 \%$ of the overall variation in lipids, and the random effect of year accounted for $3 \%$ of the explained variation (Table 3). Averaging across age, sex, and region, least square mean estimate of lipids in decoy-harvested geese was $41.1 \mathrm{~g}(95 \% \mathrm{CI}=26.2-55.9 ; 38.7 \%$ decrease $)$ lower than individuals collected by jump-shooting (Fig. 4A). In contrast to lesser snow geese, lipid content did not increase with increasing latitude of region of harvest. Rather, average lipid content initially decreased after collections in Arkansas such that individuals collected in Missouri and Nebraska had $28.1 \mathrm{~g}(95 \% \mathrm{CI}=10.2-45.9 ; 26.9 \%$ decrease $)$ and $33.9 \mathrm{~g}$ (95\% CI $=14.7-53.1 ; 32.4 \%$ decrease) less lipids, respectively. Lipid levels from individuals collected in South Dakota did not differ from those of individuals collected in Arkansas.

Protein content in Ross's geese varied only by the main effects of region, and decreased as latitude of collection region increased. Protein content was not influenced by harvest type, however, the $P$-value for the slope coefficient of harvest type approximated our designated alpha level $(P=0.067$; Table 3$)$. Our model explained approximately $28 \%$ of the overall variation in the data, and the random effect of year did not account for any portion of the explained variation (Table 3). 
(A)

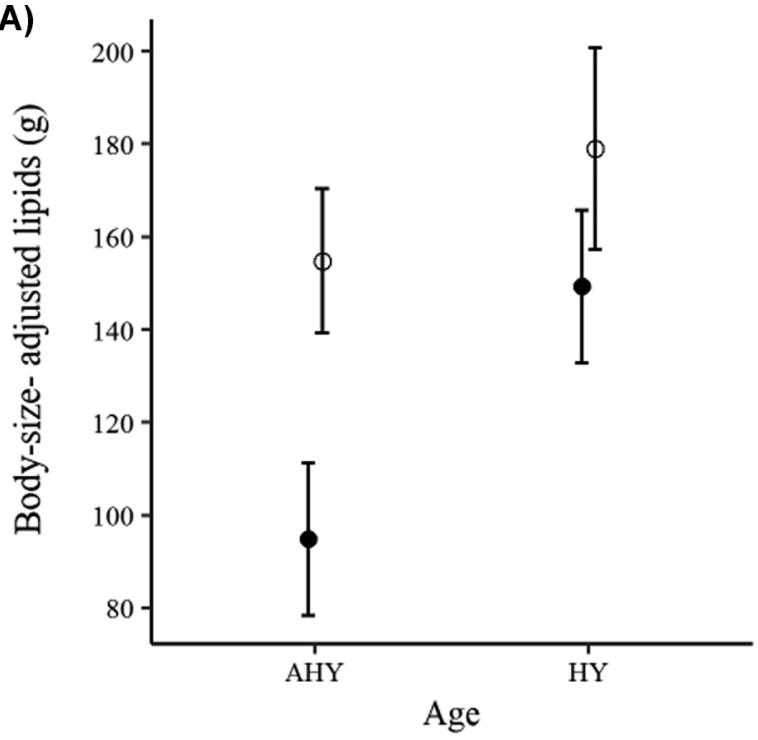

(C)

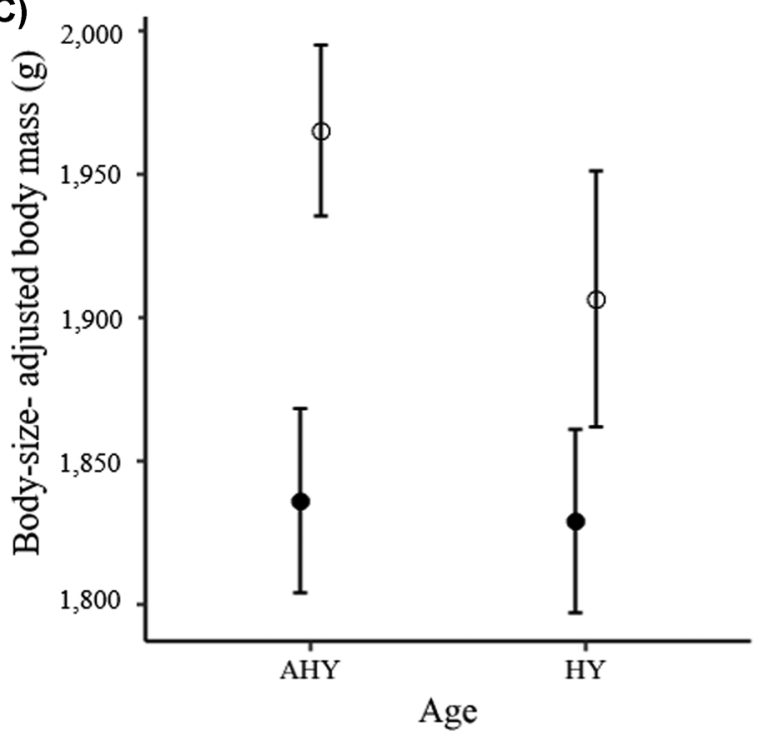

(B)

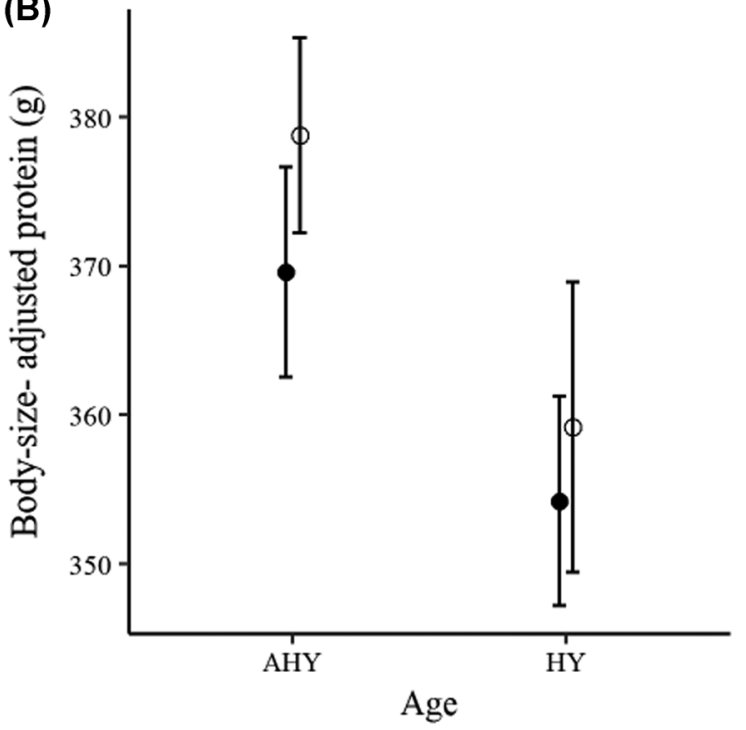

(D)

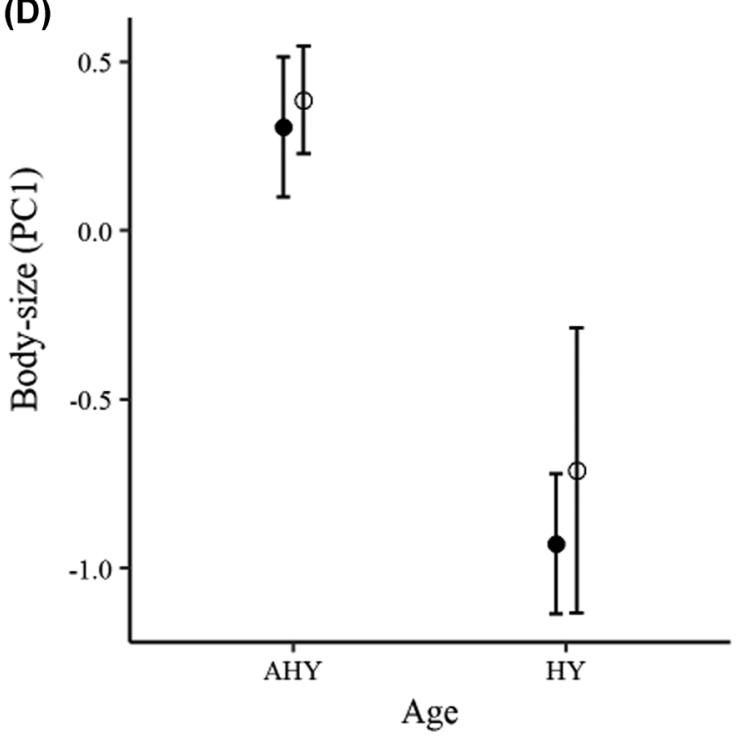

Figure 2. Least-square means and $95 \%$ confidence intervals of lipid content (A), protein content (B), ingesta-free body mass (C), and body size (D) in lesser snow geese $(n=759)$ by age class (after hatch year [AHY] and hatch year [HY]) and harvest type collected during the spring Light Goose Conservation Order in 2015 and 2016. Closed circles are decoy-harvested individuals and open circles are jump-shot individuals.

Ingesta-free body mass in Ross's geese varied by the main effects of age, region of harvest, and harvest type, but interactions between harvest type and age, and harvest type and harvest region were not significant (Table 3). Our model explained approximately $51 \%$ of the overall variation in the data, and the random effect of year accounted for $6 \%$ of the explained variation (Table 3). Averaging across age, sex, and region, the least square mean estimate of ingestafree body mass in decoy-harvested Ross's geese was $118.9 \mathrm{~g}$ (95\% CI $=83.4-154.5 ; 9.2 \%$ decrease) lower than individuals collected by jump-shooting. Ingesta-free body mass closely followed patterns observed in lipid content across harvest regions. Least square mean estimates of ingesta-free body mass of birds in Missouri and Nebraska were $79.9 \mathrm{~g}$ $(95 \% \mathrm{CI}=37.5-122.5 ; 6.2 \%$ decrease $)$ and $88.6 \mathrm{~g}(95 \%$ $\mathrm{CI}=43.0-134.2 ; 6.9 \%$ decrease), respectively, lower relative to individuals collected in Arkansas. Individuals collected in
South Dakota were not different in estimates of ingesta-free body mass, relative to those collected in Arkansas. Body size in Ross's geese varied with main effects of sex and the interaction between harvest type and age such that decoyshot $\mathrm{HY}$ individuals were larger than jump-shot $\mathrm{HY}$ individuals (Table 4). Body size did not differ between harvest types for AHY individuals (Fig. 5).

\section{DISCUSSION}

Our findings support the harvest condition bias hypothesis and expand it to include geese during spring migration. Although the harvest condition bias hypothesis has received support for shorter-lived duck species (Greenwood et al. 1986, Hepp et al. 1986, Pace and Afton 1999), we directly identified condition biases in a longer-lived goose species, which contrasts the only other study known to test this hypothesis in geese (Morez et al. 2000). We found that both 


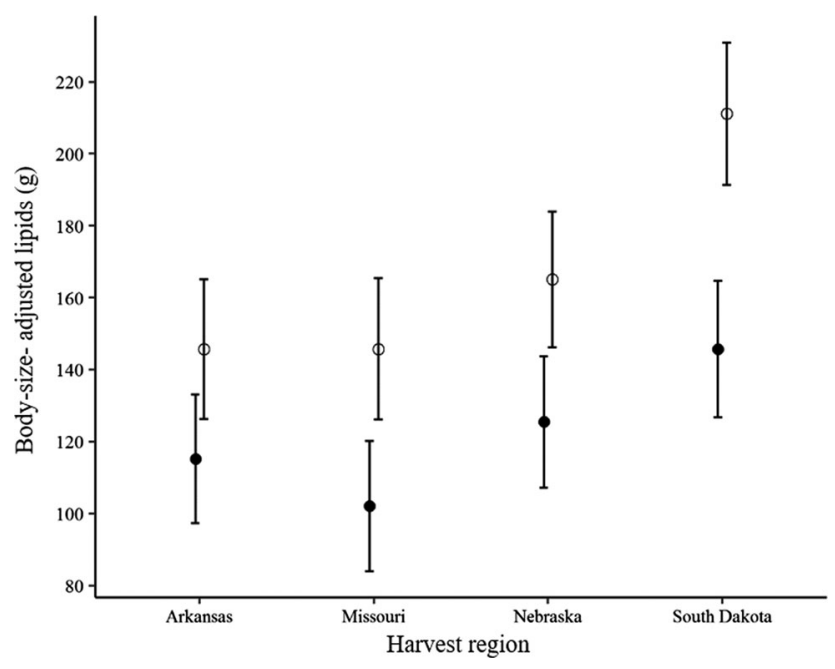

Figure 3. Least square means and $95 \%$ confidence intervals of lipid content in lesser snow geese $(n=759)$ by harvest region and harvest type collected during the spring Light Goose Conservation Order in 2015 and 2016. Closed circles are decoy-harvested individuals and open circles are jump-shot individuals.

age classes of lesser snow and Ross's geese harvested over decoys had lower size-adjusted body mass and lipid reserves, relative to individuals harvested by jump-shooting. Despite canalization in long-lived species (Péron et al. 2016), our study indicates that the LGCO harvest primarily removes from the population a cohort of individuals of lower body condition that are likely more risk-prone resulting from an increased need to acquire energy stores used for migration. Therefore, future harvest assessments on population change in light geese could benefit from additionally considering the effects of removing individuals that likely have lower overall fitness.

Spring migration is an energetically costly event and requires a balance of water, protein, and lipid reserves for optimal energy expenditure (Jenni and Jenni-Eiermann 1998, Klaassen et al. 2006). Although we predicted that condition biases would result in samples with lower lipid and protein content, lower body mass in decoy-harvested individuals

Table 2. Results of a general linear model explaining variation in body size (principal component 1 [PC1]) of lesser snow geese $(n=759)$ collected during the spring Light Goose Conservation Order in 2015 and 2016. Predictor variables included sex (male or female), age (after hatch year [AHY] or hatch year [HY]), and harvest type (decoy or jump-shot).

\begin{tabular}{lccc}
\hline Variables & Estimate & & $\mathbf{9 5 \%}$ CI \\
\hline Intercept $^{\mathrm{a}}$ & $-0.66^{* * *}$ & \pm & 0.25 \\
Sex (male) & $1.93^{* * * *}$ & \pm & 0.25 \\
Age (HY) & $-0.96^{* * * *}$ & \pm & 0.39 \\
Sex $\times$ age (male, HY) & $-0.54^{*}$ & \pm & 0.45 \\
Harvest type (jump) & 0.08 & \pm & 0.26 \\
Harvest type $\times$ age (jump, HY) & 0.14 & \pm & 0.54 \\
Number of observations & & 759 & \\
Adjusted. $R^{2}$ & & 0.33 & \\
Root mean square error & & & \\
\hline & & & \\
${ }^{*} P<0.05$. & & \\
${ }^{* * *} P<0.01$. & \\
${ }^{* * * * *} P<0.001$. & \\
${ }^{a}$ Intercept referenced on adult female geese collected over decoys.
\end{tabular}

coincided with reduced lipid content only, not protein reserves. Our results are consistent with the use of lipid reserves as the primary fuel source for migration (Jenni and Jenni-Eiermann 1998). Because of their high energy content per unit, lipid reserves contain 8-10 times more labile energy than protein or glycogen (McWilliams et al. 2004). We also found that confidence intervals around the effect size of harvest type as a predictor for protein content in Ross's geese narrowly overlapped with zero (95\% CI $=-0.48-23.54$; Table 3), suggesting it may be plausible for decoy-harvested geese to also have reduced protein levels. Protein can be catabolized for energy prior to starvation, but these stores largely provide the structural capacity for flight in waterfowl (McWilliams et al. 2004). Therefore, based on our results, individuals with reduced protein, in addition to reduced lipid reserves, would likely have increased harvest vulnerability. Overall, our results support the harvest condition bias hypothesis that decoy-harvested individuals are more vulnerable to harvest, resulting from a reduction in their primary source of energetic reserves that leads to an increased response to decoys that signal foraging opportunities (Greenwood et al. 1986, Pace and Afton 1999).

Moreover, regardless of harvest type, increases in body mass associated with greater latitude were explained by improved lipid reserves, with a concurrent decline in protein reserves. Long-term declines of protein reserves in prebreeding lesser snow and Ross's geese arriving to nesting colonies were documented from 1993-2008 (Traylor 2010). Yet, protein reserves for these species remained unchanged during the same time period on the Canadian prairies, which suggests that protein limitation occurs north of the Canadian prairies (Ross et al. 2017) and outside our study collection area. Decreases in protein at earlier stages of migration observed in our study may be in part a necessity to maintain optimum wing loading while accumulating lipid reserves, thus requiring a concurrent reduction in protein reserves (Klaassen 1996). Reduced protein could be an artifact of food availability throughout the landscape of our study area, where the predominant food type for light geese was waste corn, which is carbohydrate rich but has low protein content (Abraham et al. 2005).

The role of reduced body condition in harvest vulnerability occurred at different magnitudes between adults and juveniles in our study. In general, juvenile light geese have greater harvest vulnerabilities compared to adults during the regular harvest season (Leafloor et al. 2012) and it has been hypothesized this increased harvest vulnerability is a result of limited experience (i.e., increased naivety to decoys) and poorer body condition relative to older birds (Morez et al. 2000, Alisauskas et al. 2006). Morez et al. (2000) did not find evidence for a condition bias (based on size-adjusted total body mass) in adult greater snow geese sampled between 1993 and 1995 but did report support for greater harvest vulnerability of juvenile geese that exhibited lower body condition at banding. In our study, however, we found lipid condition biases for decoy-harvested geese were greater for adults (38.7\% decrease) compared to juveniles (16.5\% decrease). Additionally, despite overall lower body mass, 
Table 3. Results of general linear mixed models explaining variation in lipid content ( $\mathrm{g}$ ), protein content ( $\mathrm{g}$ ), and ingesta-free body mass ( $\mathrm{g}$ ) of Ross's geese ( $n=154)$ collected during the spring Light Goose Conservation Order in 2015 and 2016. Predictor variables included sex (male or female), age (after hatch year $[\mathrm{AHY}]$ or hatch year $[\mathrm{HY}]$ ), harvest region (AR, MO, NE, SD), and harvest type (decoy or jump-shot).

\begin{tabular}{|c|c|c|c|c|c|c|c|c|c|}
\hline \multirow[b]{2}{*}{ Variables } & \multicolumn{3}{|c|}{ Lipid model } & \multicolumn{3}{|c|}{ Protein model } & \multicolumn{3}{|c|}{ Body mass model } \\
\hline & Estimate & & $95 \% \mathrm{CI}$ & Estimate & & $95 \% \mathrm{CI}$ & Estimate & & 95\% CI \\
\hline Intercept $^{\mathrm{a}}$ & $94.06^{* * *}$ & \pm & 24.00 & $238.81^{* * *}$ & \pm & 10.73 & $1257.14^{\text {**** }}$ & \pm & 64.83 \\
\hline Age $(\mathrm{HY})$ & -4.32 & \pm & 17.70 & -5.46 & $\overline{ \pm}$ & 8.71 & $-56.50^{*}$ & \pm & 45.60 \\
\hline Region (MO) & -27.30 & \pm & 26.52 & -9.20 & $\overline{ \pm}$ & 13.11 & -66.22 & \pm & 67.66 \\
\hline Region (NE) & $-37.29^{*}$ & \pm & 26.47 & $-17.86^{* *}$ & $\overline{ \pm}$ & 13.10 & $-94.38^{* *}$ & \pm & 67.33 \\
\hline Region (SD) & -14.12 & \pm & 23.39 & -10.27 & $\overline{ \pm}$ & 11.58 & -44.39 & \pm & 59.37 \\
\hline Harvest type $\times$ region (jump, MO) & -1.58 & \pm & 32.31 & 6.87 & \pm & 15.99 & -27.53 & \pm & 82.93 \\
\hline Harvest type $\times$ region (jump, NE) & 6.70 & $\overline{ \pm}$ & 34.68 & 5.28 & $\overline{ \pm}$ & 17.18 & 11.59 & $\overline{ \pm}$ & 88.01 \\
\hline Harvest type $\times$ region (jump, SD) & -0.32 & \pm & 29.72 & -3.35 & \pm & 14.72 & 31.69 & \pm & 75.46 \\
\hline Marginal $R^{2}$ & & $0 . \overline{3} 4$ & & & 0.28 & & & 0.45 & \\
\hline Conditional $R^{2}$ & & 0.37 & & & 0.28 & & & 0.51 & \\
\hline Variance: year (intercept) & & 53.51 & & & 2.11 & & & 809.26 & \\
\hline
\end{tabular}

${ }^{*} P<0.05$

** $P<0.01$.

*** $P<0.001$.

${ }^{a}$ Intercept referenced on adult female geese collected in Arkansas over decoys.

juvenile geese maintained lipid reserves equal to adults, or greater in the case of lesser snow geese. Juvenile lipid content levels comparable to those observed in adults may be a product of their social behavior to remain in family groups for at least a year after hatching, thereby benefitting from parental provision that affords access to advantageous foraging locations (Prevett and MacInnes 1980). An additional consideration for high lipid content in juveniles could be associated with timing of our spring sampling. It may be a reasonable assumption that variation in body condition among juveniles is greater earlier in the first year of life, but processes of natural and harvest mortality during the fall and winter remove those with lower fitness so that only fitter individuals remain into the spring.

We used jump-shooting as a method to collect geese from the general population to serve as a control group for decoyshot individuals. We selected jump-shooting techniques because they allowed for the sampling of individuals without the presence of decoys and presumably mixed individuals in the air from within the flock when they were flushed. The control sample should be truly random, but assessing and validating randomness is challenging and jump-shooting methods may have their own biases. Sneaking up on foraging geese required approaching the flock from an edge and some evidence points towards more dominant family groups capitalizing edges along a feeding flock (Black et al. 1992, Rowcliffe et al. 2004, Poisbleau et al. 2006). Although we were deliberate in flushing birds prior to shooting to maximize the mixing of individuals, it is possible that these samples contained a disproportionate number of individuals who were in better body condition because of social dominance. We jump-shot individuals from both foraging and loafing flocks and intentionally flushed birds into the air before shooting. Although
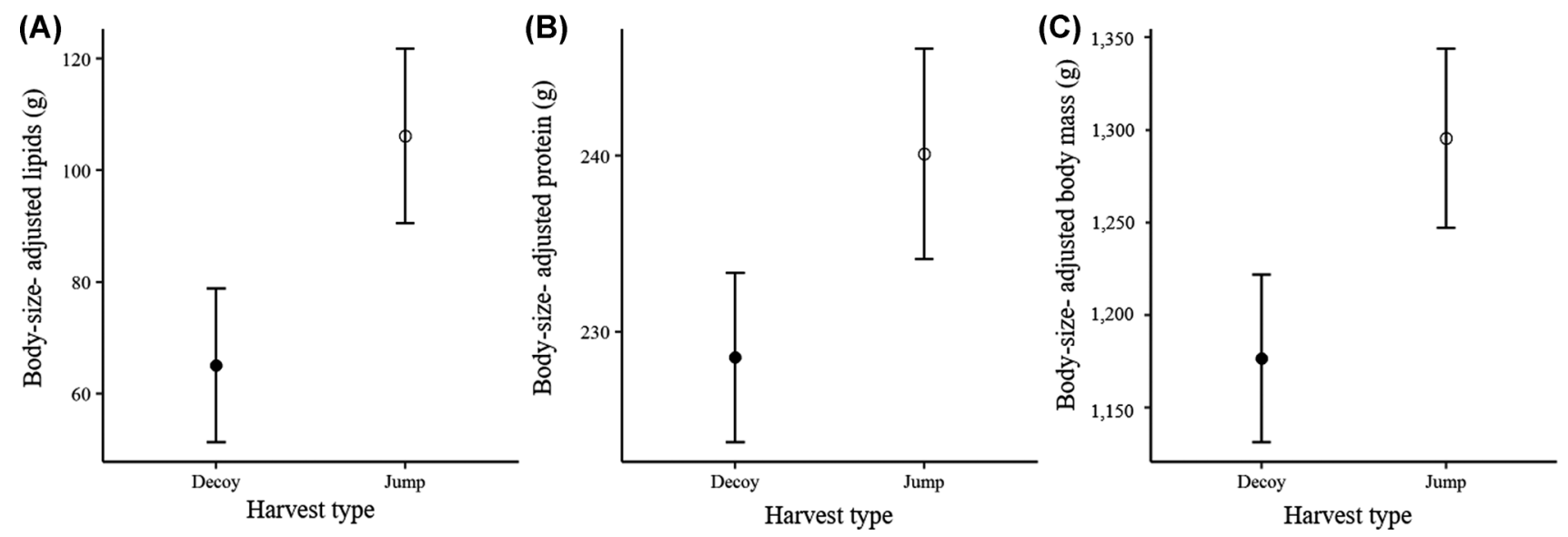

Figure 4. Least square means and $95 \%$ confidence intervals of lipid content (A), protein content (B), and ingesta-free body mass (C) in Ross's geese $(n=154)$ by harvest type collected during the spring Light Goose Conservation Order in 2015 and 2016. Closed circles are decoy-harvested individuals and open circles are jump-shot individuals. 
Table 4. Results of a general linear model explaining variation in body size (principal component 1 [PC1]) of Ross's geese $(n=154)$ collected during the spring Light Goose Conservation Order in 2015 and 2016. Predictor variables included sex (male or female), age (after hatch year [AHY] or hatch year [HY]), and harvest type (decoy or jump-shot).

\begin{tabular}{lccc}
\hline Variables & Estimate & & 95\% CI \\
\hline Intercept $^{\mathrm{a}}$ & $-0.64^{*}$ & \pm & 0.56 \\
Sex (male) & $1.57^{* * *}$ & \pm & 0.54 \\
Age (HY) & -0.74 & \pm & 0.89 \\
Sex $\times$ age (male, HY) & -0.43 & \pm & 1.05 \\
Harvest type (jump) & 0.02 & \pm & 0.55 \\
Harvest type $\times$ age (jump, HY) & $-1.69^{* *}$ & \pm & 1.13 \\
Number of observations & & 154 & \\
Adjusted $R^{2}$ & & 0.33 & \\
Root mean square error & & 1.44 & \\
\hline
\end{tabular}

* $P<0.05$.

** $P<0.01$.

*** $P<0.001$.

${ }^{\text {a }}$ Intercept referenced on adult female geese collected over decoys.

we cannot confirm that birds collected using this method were entirely representative of the general population, we assumed that these birds were more representative of the general population compared to decoy-shot individuals, consistent with previous work in ducks (Greenwood et al. 1986). However, even if jump-shot birds are not entirely representative of the general population, our results demonstrate that individuals with greater body condition are not the predominant type of bird harvested over decoys.

Differences in body condition between decoy-harvested and jump-shot individuals are likely a reflection of population heterogeneity resulting from individual variation in decisions or abilities to allocate time, energy, and nutrients to enhance their fitness (Stearns 1992, Vedder and Bouwhuis 2018). Consequently, heterogenous body

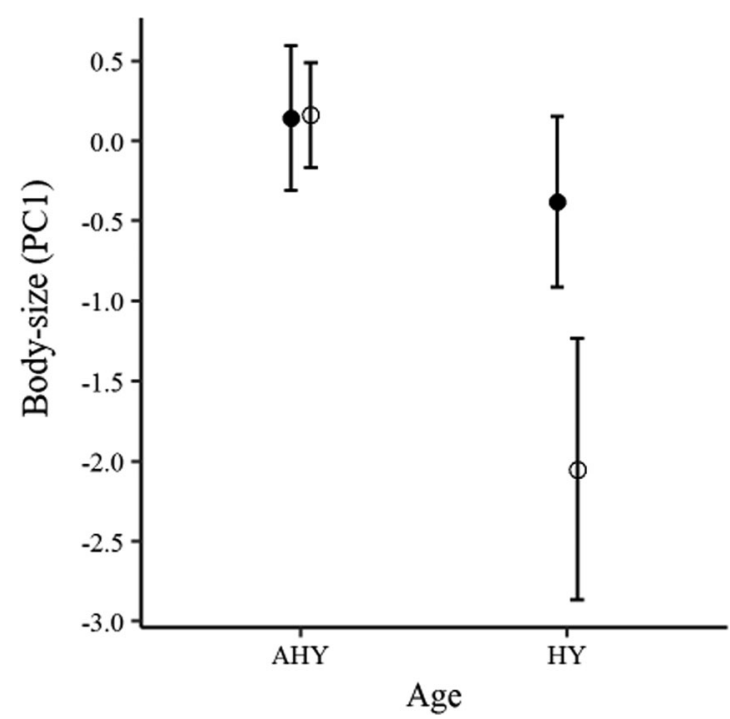

Figure 5. Least square means and $95 \%$ confidence intervals of body size (first principal component [PC1]), in Ross's geese $(n=154)$ by age class (after hatch year [AHY] and hatch year [HY]) and harvest type collected during the spring Light Goose Conservation Order in 2015 and 2016. Closed circles are decoy-harvested individuals and open circles are jumpshot individuals. condition has been linked to partially explain differential fitness rates, such that poorer quality individuals have increased probabilities of mortality (Conroy et al. 1989, Sedinger and Herzog 2012, Péron 2013) or reduced breeding propensity (Béchet et al. 2004, Souchay et al. 2014). Therefore, in our study, observed differences in body condition within and between harvest types suggest nonhomogenous survival rates among adult lesser snow and Ross's geese.

Homogenous estimation of adult (categorized either as $>1$ or 2 years old) survival is a simplification of population structure and ignores potential variation in individuals experiencing differential life-history events. For instance, Iverson et al. (2014) separately analyzed survival between breeding Canada geese (Branta canadensis) and nonreproductive individuals (determined by the proportion of juveniles in flocks during routine banding) and found that non-reproductive geese had lower survival than successful breeders and that their harvest served to partially compensate the overall effect of hunter harvest. Given the development of analytical methods to evaluate heterogeneous survival rates (Pledger and Schwarz 2002, Gimenez et al. 2018), future studies could assess individual variation among cohorts to estimate the range and distribution of population vital rates and better describe effects of different realized life histories to fitness.

Additional considerations, such as annual and interseasonal environmental variability and hunting tactics may provide further inference for evaluating the influence of body condition on harvest vulnerability. In general, differences in body condition between decoy-harvested individuals and the overall population are likely a spatially and temporally dynamic trait, rather than a static pattern. For example, greatest annual participation in the LGCO often coincides with peak migration or after peak migration to capitalize on the increased naivety to decoys of juveniles that often lag in migration phenology (D. N. Fowler, University of Missouri, personal observation). In contrast, harvest aimed at the vanguard is often more challenging because this cohort is largely comprised of adults whose earlier migration phenology coincides with improved body condition and advanced nest initiation (Ebbinge and Spaans 1995, Bêty et al. 2003). Although we did not sample geese in the vanguard of migration, harvest still occurs for this group and it is possible that differences in body condition are smaller between decoy-harvested and surviving early migrants. Secondly, environmental pressures, such as weather severity, experienced during migration could differentially affect individuals within the population dispersed spatially across a flyway (Bêty et al. 2004, Robson and Barriocanal 2008). Therefore, the extent of difference in individual body condition between harvest types could vary annually or within the season dependent upon conditions encountered during migration. Nonetheless, our 2-year assessment suggests that, at least during periods of peak migration and peak LGCO participation, harvested individuals have poorer body condition than birds in the general population. 


\section{MANAGEMENT IMPLICATIONS}

To successfully reduce adult survival rates, the LGCO would need to generate substantially greater annual adult harvest rates (Leafloor et al. 2012). Our findings provide an additional consideration regarding the potential for harvest to reduce population size through reduced survival rates. The likely presence of heterogeneous survival via variation in body condition allows for possible harvest compensation without requiring density dependence (Lebreton 2005, Caudill et al. 2017). Therefore, disproportionate harvest of poorerconditioned lesser snow and Ross's geese in decoy-hunting situations may serve as an additional challenge against any realized effects of harvest. Indeed, Lindberg et al. (2013) found that compensation for harvest mortality decreased as the proportion of high-quality individuals harvested increased. Harvest has generally been considered additive in most goose species given their high natural survival rates (Rexstad 1992, Koons et al. 2014); however, current observed levels of harvest in light geese fail to indicate evidence of additivity (Calvert et al. 2017). Therefore, in addition to insufficient harvest rates, harvest of individuals exhibiting poorer body condition relative to the general population suggests that the LGCO primarily pre-emptively removes individuals from the population that are more likely to die of natural mortality at later stages of spring migration.

\section{ACKNOWLEDGMENTS}

Any use of trade, firm, or product names is for descriptive purposes only and does not imply endorsement by the United States Government. L. W. Naylor, R. J. Murano, and A. H. Raedeke provided help identifying collection sites. A. D. Engel, H. M. Johnson, J. B. Piercefield, and B. A. Woodall assisted with data collection and sample processing. J. D. Firman provided laboratory assistance. We thank all the participants in the LGCO who submitted birds for our study. Finally, we thank R. Alisauskas and an anonymous reviewer for their help in improving this manuscript. Data are available upon request. The Missouri Cooperative Fish and Wildlife Research Unit is jointly sponsored by the Missouri Department of Conservation, University of Missouri, United States Fish and Wildlife Service, United States Geological Survey, and Wildlife Management Institute. Funding for this project was provided by the Nebraska Game and Parks Commission through the United States Fish and Wildlife Service's Sportfish and Wildlife Restoration Program and by Ducks Unlimited Canada's Institute for Wetland and Waterfowl Research.

\section{LITERATURE CITED}

Abraham, K. F., R. L. Jefferies, and R. T. Alisauskas. 2005. The dynamics of landscape change and snow geese in mid-continent North America. Global Change Biology 11:841-855.

Alisauskas, R. T. 2002. Arctic climate, spring nutrition, and recruitment in midcoontinent lesser snow geese. Journal of Wildlife Management 66:181-193.

Alisauskas, R. T., K. L. Drake, S. M. Slattery, and D. K. Kellett. 2006. Neckbands, harvest, and survival of Ross's geese from Canada's central arctic. Journal of Wildlife Management 70:89-100.
Alisauskas, R. T., R. F. Rockwell, K. W. Dufour, E. G. Cooch, G. Zimmerman, K. L. Drake, J. O. Leafloor, T. J. Moser, and E. T. Reed. 2011. Harvest, survival, and abundance of midcontinent lesser snow geese relative to population reduction efforts. Wildlife Monographs 179:1-42.

Anderson, D. R., and K. P. Burnham. 1976. Population ecology of the mallard: VI. The effect of exploitation on survival. U.S. Fish and Wildlife Service, Washington D.C., USA.

Ankney, C. D., and C. D. MacInnes. 1978. Nutrient reserves and the reproductive performance of female lesser snow geese. Auk 95:459-471.

Baldassarre, G. A. 2014. Ducks, geese, and swans of North America. John Hopkins University Press, Baltimore, Maryland, USA.

Barton, K. 2017. MuMIn: multi-model inference. R package version 1.40.0. R Foundation for Statistical Computing, Vienna, Austria.

Bates, D., M. Mächler, B. Bolker, and S. Walker. 2015. Fitting linear mixedeffects models using lme4. Journal of Statistical Software 67(1):1-48.

Batt, B. D. J., editor. 1997. Arctic ecosystems in peril: report of the Arctic Goose Habitat Working Group. U.S. Fish and Wildlife Service, Washington, D.C., USA, and Canadian Wildlife Service, Ottawa, Ontario, Canada.

Béchet, A., J.-F. Giroux, and G. Gauthier. 2004. The effects of disturbance on behaviour, habitat use and energy of spring staging snow geese. Journal of Applied Ecology 41:689-700.

Bêty, J., G. Gauthier, and J.-F. Giroux. 2003. Body condition, migration, and timing of reproduction in snow geese: a test of the conditiondependent model of optimal clutch size. American Naturalist 162:110-121.

Bêty, J., J.-F. Giroux, and G. Gauthier. 2004. Individual variation in timing of migration: causes and reproductive consequences in greater snow geese (Anser caerulescens atlanticus). Behavioral Ecology and Sociobiology 57:1-8.

Black, J. M., C. Carbone, R. L. Wells, and M. Owen. 1992. Foraging dynamics in goose flocks: the cost of living on the edge. Animal Behaviour 44:41-50.

Blums, P., J. D. Nichols, J. E. Hines, M. S. Lindberg, and A. Mednis. 2005. Individual quality, survival variation and patterns of phenotypic selection on body condition and timing of nesting in birds. Oecologia 143:365-376.

Bonenfant, C., J. Gaillard, T. Coulson, M. Festa-Bianchet, A. Loison, M. Garel, L. E. Loe, P. Blanchard, N. Pettorelli, and N. Owen-Smith. 2009. Empirical evidence of density-dependence in populations of large herbivores. Advances in Ecological Research 41:313-357.

Calvert, A. M., R. T. Alisauskas, and D. K. Kellett. 2019. Fitness heterogeneity in adult snow and Ross's geese: Survival is higher in females with brood patches. The Auk. 136: In Press.

Calvert, A. M., R. T. Alisauskas, and G. C. White. 2017. Annual survival and seasonal hunting mortality of midcontinent snow geese. Journal of Wildlife Management 81:1009-1020.

Caudill, D., M. R. Guttery, T. M. Terhune, J. A. Martin, G. Caudill, D. K. Dahlgren, and T. A. Messmer. 2017. Individual heterogeneity and effects of harvest on greater sage-grouse populations. Journal of Wildlife Management 81:764-765.

Clark, J. M. 2007. Models for ecological data. Princeton University Press, Princeton, New Jersey, USA.

Conroy, M. J., G. R. Costanzo, and D. B. Stotts. 1989. Winter survival of female American black ducks on the Atlantic Coast. Journal of Wildlife Management 53:99-109.

Conroy, M. J., and D. G. Krementz. 1990. A review of the evidence for the effects of hunting on American black duck populations. Transactions of the North American Wildlife and Natural Resources Conference 55:501-517.

Cooch, E. G., M. Guillemain, G. S. Boomer, J.-D. Lebreton, and J. D. Nichols. 2014. The effects of harvest on waterfowl populations. Wildfowl Special Issue No 4:220-276.

Dufour, W. K., C. D. Ankney, and J. P. Weatherhead. 1993. Condition and vulnerability to hunting among mallards staging at Lake St. Clair, Ontario. Journal of Wildlife Management 57:209-215.

Dzubin, A., and E. G. Cooch. 1992. Measurements of geese: general field methods. California Waterfowl Association, Sacramento, California, USA.

Ebbinge, B. S., and B. Spaans. 1995. The importance of body reserves accumulated in spring staging areas in the temperate zone for breeding in dark-bellied brent geese Branta b. bernicla in the high Arctic. Journal of Avian Biology. 105-113. 
Fowler, D. N., K. J. Kuechle, B. A. Woodall, M. P. Vrtiska, and E. B. Webb. 2018. Evaluating indices of lipid and protein content in lesser snow and Ross's geese during spring migration. Wildlife Society Bulletin 42:295-303.

Fox, A. D., and J. Madsen. 2017. Threatened species to super-abundance: the unexpected international implications of successful goose conservation. Ambio 46:179-187.

Gimenez, O., E. Cam, and J. M. Gaillard. 2018. Individual heterogeneity and capture-recapture models: What, why and how? Oikos 127:664-686.

Greenwood, H. R., R. G. Clark, and P. J. Weatherhead. 1986. Condition bias of hunter-shot mallards (Anas platyrhynchos). Canadian Journal of Zoology 64:599-601.

Harrison, X. A., L. Donaldson, M. E. Correa-Cano, J. Evans, D. N. Fisher, C. E. D. Goodwin, B. S. Robinson, D. J. Hodgson, and R. Inger. 2018. A brief introduction to mixed effects modelling and multi-model inference in ecology. PeerJ 6:e4794.

Harvey, W. 1960. Least-squares analysis of data with unequal subclass numbers. Technical report, Agricultural Research Service, U.S. Department of Agriculture, Washington D.C., USA

Hénaux, V., L. A. Powell, M. P. Vrtiska, and K. A. Hobson. 2012. Establishing winter origins of migrating lesser snow geese using stable isotopes. Avian Conservation and Ecology 7:5.

Hepp, G. R., R. J. Blohm, R. E. Reynolds, J. E. Hines, and J. D. Nichols. 1986. Physiological condition of autumn-banded mallards and its relationship to hunting vulnerability. Journal of Wildlife Management 50:177-183

Higgins, K. F., D. E. Naugle, and K. J. Forman. 2002. A case study of changing land use practices in the Northern Great Plains, U.S.A.: an uncertain future for waterbird conservation. Waterbirds 25:42-50.

Hill, M. R. J., R. T. Alisauskas, C. D. Ankney, and J. O. Leafloor. 2003. Influence of body size and condition on harvest and survival of juvenile Canada geese. Journal of Wildlife Management 67:530-541.

Hobbs, N. T., H. Andrén, J. Persson, M. Aronsson, S. E. Applications, N. July, N. T. Hobbs, H. Andrén, J. Persson, M. Aronsson, and G. Chapron. 2012. Native predators reduce harvest of reindeer by Sámi pastoralists. Ecological Applications 22:1640-1654.

Horwitz, W. 2006. Official methods of analysis of AOAC International. AOAC International, Gaithersburg, Maryland, USA.

Iverson, S. A., E. T. Reed, R. J. Hughes, and M. R. Forbes. 2014. Age and breeding stage-related variation in the survival and harvest of temperatebreeding Canada geese in Ontario. Journal of Wildlife Management 78:24-34.

Jenni, L., and S. Jenni-Eiermann. 1998. Fuel supply and metabolic constraints in migrating birds. Journal of Avian Biology 29:521-528.

Johnson, F. A., B. K. Williams, J. D. Nichols, J. E. Hines, W. L. Kendall, G. W. Smith, and D. F. Caithamer. 1993. Developing an adaptive management strategy for harvesting waterfowl in North America. Transactions of the North American Wildlife and Natural Resources Conference 58:565-583.

Kadane, J. B., and N. A. Lazat. 2004. Methods and criteria for model selection. Journal of the American Statistical Association 99:279-209.

Klaassen, M. 1996. Metabolic constraints on long-distance migration in birds. Journal of Experimental Biology 199:57-64.

Klaassen, M., K. F. Abraham, R. L. Jefferies, and M. P. Vrtiska. 2006. Factors affecting the site of investment, and the reliance on savings for arctic breeders: the capital-income dichotomy revisited. Ardea 94:371-384.

Koons, D. N., R. F. Rockwell, and L. M. Aubry. 2014. Effects of exploitation on an overabundant species: the lesser snow goose predicament. Journal of Animal Ecology 3:365-374.

Kruse, K. L., and D. Fronczack. 2013. Light geese in the Central and Mississippi Flyways. U.S. Fish and Wildlife Service, Denver, Colorado, USA.

Kuznetsova, A., P. B. Brockhoff, and R. H. B. Christensen. 2017. lmerTest package: tests in linear mixed effects models. Journal of Statistical Software 82(13):1-26.

Leafloor, J. O., T. J. Moser, and B. D. J. Batt. 2012. Evaluation of special management measures for midcontinent lesser snow geese and Ross's geese. Arctic Goose Joint Venture Special Publication. U.S. Fish and Wildlife Service, Washington, D.C., USA, and Canadian Wildlife Service, Ottawa, Ontario, Canada

Lebreton, J.-D. 2005. Dynamic and statistical models for exploited populations. Australian and New Zealand Journal of Statistics 47:49-63.
Lindberg, M. S., J. S. Sedinger, and J. Lebreton. 2013. Individual heterogeneity in black brant survival and recruitment with implications for harvest dynamics. Ecology and Evolution 3:4045-4056.

McWilliams, S. R., C. Guglielmo, B. Pierce, and M. Klaassen. 2004. Flying, fasting, and feeding in birds during migration: a nutritional and physiological ecology perspective. Journal of Avian Biology 35:377-393.

Morez, V., G. Gauthier, and A. Reed. 2000. Effect of body condition on vulnerability of greater snow geese to hunting and capture. Journal of Wildlife Management 64:875-886.

Murray, D. L., M. G. Anderson, and T. D. Steury. 2010. Temporal shift in density dependence among North American breeding duck populations. Ecology 91:571-581.

Nakagawa, S., and H. Schielzeth. 2013. A general and simple method for obtaining $\mathrm{R}^{2}$ from generalized linear mixed-effects models. Methods in Ecology and Evolution 4:133-142.

Nevoux, M., J. Forcada, C. Barbraud, J. Croxall, and H. Weimerskirch. 2010. Bet-hedging response to environmental variability, an intraspecific comparison. Ecology 91:2416-2427.

Nichols, J. D. 1991. Extensive monitoring programmes viewed as longterm population studies: the case of North American waterfowl. Ibis 133:89-98.

Owen, M., and J. M. Black. 1989. Factors affecting the survival of barnacle geese on migration from the breeding grounds. Journal of Animal Ecology 58:603-617.

Pace, R. M., III, and A. D. Afton. 1999. Direct recovery rates of lesser scaup banded in northwest Minnesota: sources of heterogeneity. Journal of Wildlife Management 63:389-395.

Péron, G. 2013. Compensation and additivity of anthropogenic mortality: life-history effects and review of methods. Journal of Animal Ecology 82:408-417.

Péron, G., J. M. Gaillard, C. Barbraud, C. Bonenfant, A. Charmantier, R. Choquet, T. Coulson, V. Grosbois, A. Loison, G. Marzolin, et al. 2016. Evidence of reduced individual heterogeneity in adult survival of long-lived species. Evolution 70:2909-2914.

Pledger, S., and C. J. Schwarz. 2002. Modelling heterogeneity of survival in band-recovery data using mixtures. Journal of Applied Statistics 29:315-327.

Poisbleau, M., H. Fritz, M. Valeix, P.-Y. Perroi, S. Dalloyau, and M. M. Lambrechts. 2006. Social dominance correlates and family status in wintering dark-bellied brent geese, Branta bernicla bernicla. Animal Behaviour 71:1351-1358.

Pöysä, H., J. Elmberg, G. Gunnarsson, P. Nummi, and K. Sjöberg. 2004. Ecological basis of sustainable harvesting: is the prevailing paradigm of compensatory mortality still valid? Oikos 104:612-615.

Prevett, J. P., and C. D. MacInnes. 1980. Family and other social groups in snow geese. Wildlife Monographs 71:3-46.

R Development Core Team. 2018. R: a language and environment for statistical computing. R Foundation for Statistical Computing, Vienna, Austria.

Reinecke, K. J., R. M. Kaminski, K. J. Moorehead, J. D. Hodges, and J. R. Nassar. 1989. Mississippi Alluvial Valley. Pages 203-247 in L. M. Smith, R. L. Pederson, and R. M. Kaminski, editors. Habitat management for migrating and wintering waterfowl in North America. Texas Tech University Press, Lubbock, USA.

Reinecke, K. J., and C. W. Shaiffer. 1988. A field test for differences in condition among trapped and shot mallards. Journal of Wildlife Management 52:227-232.

Rexstad, E. A. 1992. Effect of hunting on annual survival of Canada geese in Utah. Journal of Wildlife Management 56:297-305.

Robson, D., and C. Barriocanal. 2008. The influence of environmental conditions on the body mass of barn swallows (Hirundo rustica) during spring migration. Journal of Ornithology 149:473-478.

Ross, M. V., R. T. Alisauskas, D. C. Douglas, and D. K. Kellett. 2017. Decadal declines in avian herbivore reproduction: densitydependent nutrition and phenological mismatch in the Arctic. Ecology 98:1869-1883.

Rowcliffe, J. M., R. A. Pettifor, and C. Carbone. 2004. Foraging inequalities in large groups: quantifying depletion experienced by individuals in goose flocks. Journal of Animal Ecology 73:97-108.

Sedinger, J. S., and M. P. Herzog. 2012. Harvest and dynamics of duck populations. Journal of Wildlife Management 76:1108-1116. 
Sheeley, D. G., and L. M. Smith. 1989. Tests of diet and condition bias in hunter-killed northern pintails. Journal of Wildlife Management 53:765-769.

Souchay, S. G., G. G. Gauthier, and R. Pradel. 2014. To breed or not: a novel approach to estimate breeding propensity and potential trade-offs in an Arctic-nesting species. Ecology 95:2745-2756.

Stearns, S. C. 1992. The evolution of life histories. Oxford University Press, London, United Kingdom.

Traylor, J. J. 2010. Comparative breeding ecology in arctic-geese of different body size: an example in Ross's and lesser snow geese. Dissertation, University of Saskatchewan, Saskatoon, Canada.

U.S. Fish and Wildlife Service. 2005. Squaw Creek National Wildlife Refuge Comprehensive Conservation Plan. U.S. Fish and Wildlife Service, Mound City, Missouri, USA.
Vedder, O., and S. Bouwhuis. 2018. Heterogeneity in individual quality in birds: overall patterns and insights from a study on common terns. Oikos 127:719-727.

Viljugrein, H., N. C. Stenseth, G. W. Smith, and G. H. Steinbakk. 2005. Density dependence in North American ducks. Ecology 86:245-254.

Waddington, C. 1953. Genetic assimilation of an acquired character. Evolution 7:118-126.

Webb, E. B., L. M. Smith, M. P. Vrtiska, and T. G. Lagrange. 2010. Effects of local and landscape variables on wetland bird habitat use during migration through the Rainwater Basin. Journal of Wildlife Management 74:109-119.

Associate Editor: Adam Janke. 